\title{
ECONOMIC CONSIDERATIONS IN ESTABLISHING MAXIMUM PRICES IN WARTIME?
}

\author{
Donald H. Wallace* and Philip H. Coombs $\dagger$
}

Government administration of the nation's price structure is a gigantic and unenviable task. It involves substituting human calculations for the impersonal dictates of the complex market mechanism which arbitrates the conflict of powerful economic forces in peacetime. It necessitates replacing the myriad of price decisions made by thousands of individual buyers and sellers in peacetime with the judgments of a relatively few government experts. It means influencing directly the pocketbooks of numerous groups and individuals who in general profess sincere approval of a vigorous price stabilization program but who frequently petition for special treatment of their own particular prices while urging that all others be prevented from rising.

The purpose of this article is to set forth some of the more important economic considerations which are appropriate in establishing maximum wartime prices, with particular reference to the operations of the Office of Price Administration.

Such considerations are, of course, influenced by the nature of the social-economic framework within which a price administration program is conducted. The basic assumptions of our present discussion are simply those realistic conditions which confront the Office of Price Administration today. These conditions include: (I) a rapidly growing war program which has already reached the proportions of nearly I60 billion dollars; (2) substantial shortages of the necessary manpower, facilities, and materials to fulfill this program; (3) the consequent necessity of increasingly drastic direct controls over the allocation and use of economic resources; (4) the provisions of the Emergency Price Control Act of 1942 which provide the framework for the activities of the price agency; (5) the likelihood of stronger taxes and other

\footnotetext{
${ }^{2}$ Some parts of this article are based upon an unpublished paper presented by us at the annual meetings of the American Statistical Association in December, 194I. We are indebted to the Association for permission to use that paper in the preparation of this article.

*A.B., 1924, M.A., 1928, Ph.D., I931, Harvard University. Assistant Administrator, in charge of Division of Industrial Materials and Equipment, Office of Price Administration, appointed, October, $194^{\circ}$. Assistant Professor of Economics, Harvard University, I937-I939; Associate Professor of Economics, Williams College, since 1939 (on leave of absence). Author: Market Control in the Aluminum Industry (Harvard Univ. Press, I937); Co-author: International Control in Non-Ferrous Metals (Macmillan, 1937); Editor and co-author, Economic Standards of Government Price Control (TNEC Monograph No. 32). Contributor to scholarly periodicals.

+A.B., 1937, Amherst College; graduate work in economics, 1937-1940, University of Chicago, and Brookings Institution. Assistant to Director of Retail Trade and Services Division, Office of Price Administration, appointed June, r941. Instructor in Economics, Williams College, I940-I94I.
} 
fiscal measures which will, however, continue to fall far short of eliminating the growing "inflationary gap" between current spendable funds and the aggregate of available goods and services valued at present price levels; and (6) a general expectation that the war will last at least another two years.

Determination of the appropriate economic considerations in fixing wartime prices involves answering two broad questions: (I) What behavior of prices, individually and collectively, is conducive to achievement of the most effective war effort, and to minimizing post-war maladjustments? and (2) What standards and techniques of control can best achieve this sort of price behavior? In seeking answers to these questions our procedure will be to discuss, first, the general nature and objectives of the price control program; second, the activities of the Office of Price Administration to date; third, the techniques of control available to the Office of Price Administration; fourth, the appropriate economic criteria applicable to fixing individual prices or groups of prices; and fifth, the possible application of the foregoing standards and techniques to particular types of market situations; and sixth, the problems of a broad ceiling.

\section{The Nature and Objectives of the Price Control Program}

The adoption of a price control program implies that, without regulation, prices in wartime would behave in a manner detrimental both to the most efficient conduct of the war and to the civilian economy, and injurious to the post-war interests in the Nation, insofar as the latter can be considered. Similarly, it implies that there must be some "desirable" as well as "undesirable" way for prices to behave in wartime. This "desirable" behavior of the American price structure during the present emergency is perhaps best described in terms of the general objectives toward which price control actions should be directed, and in terms of the types of price behavior to be avoided.

The first objective of price control is to promote maximum efficiency of the war program. This result must be achieved not merely by preventing a wild upward surge of prices generally (which is popularly conceived to be the sole function of the price agency) but also by achieving an appropriate adjustment of price relationships. Stabilization and careful adjustment of the prices of important materials increase efficiency by reducing speculative hoarding and business uncertainties; by minimizing the wasteful competitive bidding away of materials and labor; and by facilitating the effective operation of curtailment, allocation, priority, and other direct control programs designed to allocate resources and products to most important uses, through encouraging or discouraging the desired expansion or decline in production of different things made from the same materials.

The second objective of price control is to combat the inequitable distribution of the war burden which would result under inflation through a sharp rise in living costs accompanied by grossly uneven changes in individual incomes. Such developments, particularly onerous to fixed-income groups, stimulate the familiar outcries 
against "profiteering" which are so injurious to morale and lead understandably to widespread agitation for wage increases and increase industrial disputes.

Third, price control should retard further creation of inflationary purchasing power, by preventing sharp increases in income-generating prices, by reducing the demand for wage advances, and by holding down the money costs of war materials, thus reducing the necessary amount of inflationary government borrowing.

Finally, price controls should be designed to minimize post-war maladjustments by forestalling disastrous deflation and by preventing unnecessary disruption of market structures and trade practices during the war.

Price control should be regarded as one member of a coordinated family of wartime controls which are calculated in the aggregate to achieve a prompt conversion of the economy to a wartime basis, to assure adequate production of needed supplies in the right proportion and in the shortest possible time, and to guard against needless injury to civilian living standards and unnecessary post-war hardships. Thus, price control must be supplemented by correct monetary and fiscal policy to combat inflation. It must be coordinated with programs of curtailment, priorities, and allocation to achieve the best use of resources to meet military requirements and essential civilian needs. Similarly, price control and rationing of consumer goods must be coordinated to achieve equitable distribution and a high level of morale.

A rather sharp distinction has been drawn in public discussion between (I) selective price control and (2) the over-all ceiling method. In practice, however, these two approaches may well lead to much the same result. A vigorous price control agency, confronted by rapidly growing inflationary pressures, may rapidly extend the scope of selective control to the point of forming virtually an over-all ceiling; whereas a general ceiling, simultaneously imposed on all prices, is certain to become gradually modified by selective treatment of individual commodities covered by the initial ceiling. To a considerable extent the differences are a matter of the extent and strength of inflationary pressures, of timing, and of administrative method. Before intense inflationary pressure becomes generalized throughout the economy a program of selective control has the advantages of permitting the price agency to focus its attention and energy upon a narrower range of key commodities, to act more flexibly, and to give greater consideration to the fixing of any individual price. It also permits some time for building up an administrative staff and developing a body of experience. In the face of rapidly growing inflationary pressure, however, selective control has the marked disadvantage of permitting many prices to run away while a few are being tended to; it obliges the price agency to take the initiative in fixing individual prices. A broad ceiling, on the other hand, has the advantage of stopping inflation in its tracks, and it shifts the burden of proof to individual businessmen who feel that the ceiling has treated them unjustly. The general ceiling has the disadvantages, however, of injecting a sudden rigidity into the whole price structure; it heaps upon the price agency the task of considering pleas for relief which come promptly from all directions and consequently result in the dissipation 
of administrative energies over a broader area which includes unimportant as well as important commodity prices; and it rules out the possibility of applying as thorough judgment to each individual price ceiling. If inflationary pressure mounts too rapidly, however, owing to inadequacy of fiscal control measures in the face of mounting expenditures, the over-all ceiling becomes the only effective instrument for stemming the tide and preventing severe inflation.

\section{The Activities of the Office of Price Administration to Date}

Selective price control operates on the principle of achieving the desired results with a minimum application of direct control and expenditure of administrative energy. It is conducted on the premise that certain "strategic" prices are keystones of the price structure and perform a price-determining function through their influence upon the prices of completing and competing goods, or upon the prices of the same commodity at earlier or later stages of the production-distribution structure. Thus, stabilization of the prices of the leading metals exerts a stabilizing influence upon prices of fabricated goods into which they enter.

Consequently, those prices are selected for control which have risen or threaten. to rise, which are quantitatively important in terms of government or consumer expenditures, and which are strategic in the pricing process.

The appropriate point at which to apply control depends largely on the form of the product and the characteristics of the market structure at various levels. In general, effective results are best obtained when control is applied: (a) at the last stage of production before a basic material is dispersed in many directions and into numerous fabricated forms, (b) where the products of all sellers are fairly uniform or standardized, (c) where the number of sellers is small and the merchandise assortments limited, and (d) where trade practices, including methods of quoting prices, are relatively simple. Administration of prices by government agencies is simplest in the case of privately "administered prices" where the task is merely that of controlling the controllers.

In light of the above criteria for selecting commodities and points of control, it is to be expected that the initial stages of a price control program would concentrate particularly upon basic materials such as metals, building materials, industrial chemicals, and textiles. If inflationary pressures continue, the scope of price action must be extended to semi-fabricated and finished goods and ultimately to the retail level. This assumes that price control influence is generally best transmitted from fairly early to later stages of the production-distribution structure. The reverse is, of course, true for some commodities.

The experience of the Office of Price Administration, up to the second quarter of 1942, has conformed in general to the pattern of developments described above. Major emphasis was on basic materials until the third quarter of rg4r, after which time an increasing number of semi-fabricated materials, machinery items, and 
finished goods have come within the scope of control; but the retail level had been penetrated in but few spots by the end of March, I942.

The total area over which selective controls must eventually be extended to achieve satisfactory results depends upon a host of imponderable factors and so can be determined only by experience.

The answer depends heavily upon the volume of excess spendable funds (coming both from wages and profits) and the extent to which such funds spill over from the controlled shortage items into uncontrolled areas where the inelasticity of supply. and demand engenders new price advances in these areas, rather than flowing into areas where supply is elastic or into war savings, other securities, or hoards. In other words, price control of certain key commodities may encourage saving of the funds which would otherwise have been spent on those commodities, thus reducing the inflationary gap, or it may simply shift inflationary pressure from one area to another.

Profits, wages, farm prices, and rents are strategic factors, both economically and politically, in determining the extent to which price control must be applied. Increases in one or more of these forms of income increase the total of excess spendable funds, thus exerting a further inflationary pressure on consumer goods prices. But the picture is more complex than that. Sharp profit increases, resulting either from lower unit costs of high-volume operation or from overgenerous war contracts, and the rising cost of living which results mainly from advancing farm prices and rents, are the two major stimulants of wage demands. Increased wages, in turn, frequently take the form of higher unit costs and hence become a major source of further upward pressure on prices. Obviously, all four forms of income must be stabilized, whether by direct control or by other means, if a runaway inflation is to be avoided.

Price control in the United States to date (April I, I942) already covers a much broader area than is commonly realized; yet the continued rapid growth of inflationary pressure makes it apparent that control must be extended much further if the objectives discussed earlier are to be achieved. By April I, r942, the Office of Price Administration had established II2 formal ceilings covering commodities that make up nearly $40 \%$ of the comprehensive wholesale price index of the Bureau of Labor Statistics. Informal controls had also been established over a large number of additional commodities. In the aggregate the commodities covered represented perhaps $60 \%$ of the nation's sales volume, exclusive of retail sales. The recent rapid increase in the cost of living, the prospective large growth in purchasing power, and the necessary curtailment of consumer goods make it imperative to extend control over nearly the whole of the remaining area of prices in the near future.

In applying selective price control, the Office of Price Administration has employed a wide variety of techniques, tailored to fit each particular case. Formal action has been used only when informal and indirect methods were inadequate. With the steady growth of war expenditures and disappearance of unused capacity, informal actions have, of course, become ineffective in more and more instances. 
Expansion of supply, when possible, has been viewed as the most desirable method of limiting price advances and was particularly prominent in the early stages of the present program when considerable productive slack still remained. Methods of enlarging supply include: (a) encouragement of imports by tariff reductions or negotiation with foreign governments and producers; (b) limitation of exports; (c) encouragement of full capacity operations or expansion of capacity if necessary; (d) encouragement of substitution and conservation; and (e) discouragement of excessive inventory building and speculative hoarding.

In their efforts to expand supply, the price control authorities have sought directly the cooperation of industry and have coordinated their efforts with numerous other government agencies. Such steps have been taken in the case of primary copper, zinc, lead, and aluminum, petroleum products, fats and oils, sugar, a wide variety of machines and parts, ferrous and nonferrous castings, and a number of other commodities.

Indirect limitation of price advances has also been attempted through influencing trade practices and government procurement activities. For example, commodity exchange officials were asked to limit margins and price movements on certain materials. Producers have been asked to make firm price terms in contracts for future delivery. Suggestions and requests have been made to the Army, Navy, and Procurement Division of the Treasury regarding such matters as escalator clauses, the scheduling of deliveries to avoid unnecessary bunching of supplies, and relaxation of specifications to permit substitution of abundant for scarce materials.

A third and important group of informal techniques includes warnings, suggestions, and requests to industry to withdraw price advances or avoid threatened increases. Many of the present formal ceilings were preceded by such informal actions.

Closely related are informal agreements with individual industry members to maintain existing prices for a specified period or to refrain from increases without prior consultation with the price agency. Such agreements are achieved through industry meetings, individual conferences, or correspondence. So-called "freeze letters," requesting agreements to hold prices firm, have become increasingly important in recent months as the need for prompt action has increased and as the price program has reached into areas where a uniform price for the industry is impractical due to the differentiation of products. Early in the program an effective method for holding down certain basic prices, especially of metals, was the "bell cow" technique whereby a price-freezing agreement was reached with one or more prominent price leaders who had unused capacity. Signed agreements have been employed increasingly.

As inflationary pressures grew, it was necessary to use in more and more instances a formal maximum price schedule or regulation. In addition to establishing specific maximum prices the schedule or regulation may set forth certain trade practice regulations for a particular commodity or group. 
The procedure of selective price control, as practiced by the OPA, begins with the detection of actual or threatened price increases, followed by a preliminary decision as to whether price action is likely to be necessary. Second, an economic study of the industry is undertaken, if not already under way, bringing together all available information from various government and industry sources. The third step is usually to summon members of the industry for a general conference on the facts of the situation and on the most advisable course of action. Against this background of facts and opinions, the final determination of policy is made, the details worked out, and the formal price schedule drafted, if this is the plan decided upon.

This normal procedure, which often consumes many weeks, must sometimes be telescoped into a few days or hours when there is pressing need for quick action.

The work is by no means ended when the schedule is issued. Careful observation of the price schedule's repercussions on the market must follow. When imperfections appear or when basic market shifts require revision of the schedule, the price agency must again examine the facts, confer with industry members, and then proceed to iron out wrinkles with a series of amendments if necessary.

The final task is that of securing compliance. While this is mainly a job for the lawyers, an economist's greatest resources are frequently taxed to devise a counter offensive against ingenious evaders. Some price violations are of the crude variety, such as "cash-on-the-barrel" sales in excess of established ceilings, or cash payments on the side in addition to recorded payments at the ceiling. Such unrecorded sales or cash premiums are, of course, direct violations, since all price schedules require detailed records of all transactions. More subtle forms of violation include: (I) mislabeling, such as "upgrading" of iron and steel scrap; (2) payment of excessive prices for uncontrolled merchandise in company with price-controlled items purchased at the ceiling; and (3) breaking of carload orders into less-than-carload shipments to obtain small lot premiums. The forestalling of such devious methods of evasion requires both a close acquaintance with the detailed characteristics of each commodity market and skilful drafting of price regulations.

\section{Economic Criteria in Setting Maximum Prices ${ }^{2}$}

The Price Control Act of $1942^{3}$ sets forth certain broad purposes and standards to be used by the Price Administrator in establishing maximum prices. "Whenever in the judgment of the Price Administrator the price or prices of a commodity or commodities have risen or threatened to rise to an extent or in a manner inconsistent with the purposes of this Act, he may by regulation or order establish such maximum price or maximum prices as in his judgment will be generally fair and equitable and will effectuate the purposes of this Act." (\$2(a))

The purposes of the Act are set forth in its preamble (\$I(a)) as follows:

\footnotetext{
${ }^{2}$ We do not consider in this article the criteria related to the special standards provided in the Act for maximum prices of agricultural commodities.

${ }^{3}$ Pub. L. No. 42I, 77th Cong., 2d Sess. (1942).
} 
I. "To stabilize prices and to prevent speculative, unwarranted, and abnormal increases in prices and rents";

2. "To eliminate and prevent profiteering, hoarding, manipulation, speculation, and other disruptive practices resulting from abnormal market conditions or scarcities caused by or contributing to the national emergency";

3. "To assure that defense appropriations are not dissipated by excessive prices";

4. "To protect persons with relatively fixed and limited incomes, consumers, wage earners, investors, and persons dependent on life insurance, annuities, and pensions, from undue impairment of their standard of living";

5. "To prevent hardships to persons engaged in business, to schools, universities, and other institutions, and to the Federal, State and local governments, which would result from abnormal increases in prices";

6. "To assist in securing adequate production of commodities and facilities";

7. "To prevent a post-emergency collapse of values";

8. "To stabilize agricultural prices in the manner provided for in section 3 "; and

9. "To permit voluntary. cooperation between the Government and producers, processors, and others to accomplish the aforesaid purposes."

The main purposes, apart from those concerned with the post-war interests of the country, may be summarized in three categories: (I) to prevent inflation of the general price level and all its attendant hardships, (2) to minimize the cost of the war to the Government and the people, and (3) to facilitate the maximum needed output of war goods and essential civilian goods.

The foregoing may thus be combined into the following proposition: The adverse effects of inflation upon the production of war goods and essential civilian goods, on the welfare of the people, on the cost of the war to the Government and to the people, and on post-war conditions are to be minimized by administering prices (I) so as to prevent price increases which are not necessary to promote maximum needed supplies of war and essential civilian goods, (2) so as to facilitate the production of these goods in the right proportionate amounts, and (3) so as to be generally fair and equitable.

Section 2(a) provides:

So far as practicable, in establishing any maximum price, the Administrator shall ascertain and give due consideration to the prices prevailing between October $\mathrm{I}$ and October 15 , I94I for the commodity or commodities included under such regulation or order, and shall make adjustments for such relevant factors as he may determine and deem to be of general applicability, including the following: Speculative fluctuations, general increases or decreases in costs of production, distribution, and transportation, and general increases or decreases in profits earned by sellers of the commodity or commodities, during and subsequent to the year ended October I, I94I.

The extent to which these more specific standards of the Act limit the administrative discretion of OPA in establishing maximum prices is a legal question which is discussed in another article in this volume. ${ }^{4}$ However, the broad purposes and standards of the Act as outlined above suggest both purely economic criteria in terms of prices that are no higher than adequate or necessary for the supply objectives,

- Ginsburg, The Emergency Price Control Act of 1942: Basic Authority and Sanctions, supra, at 22. 
and criteria that represent a combination of economic and ethical considerations. Costs and profits are relevant to both, although the emphasis in the case of economic criteria is more on costs and in the case of considerations of fairness more on profits.

The task of price administration is to prevent price increases, ${ }^{5}$ except where they are necessary according to the standards outlined above, and to reduce prices that have risen unduly. In passing upon potential or requested price advances the first economic criterion is simple and obvious: Price increases are necessary only when they are required in order to increase or to maintain the production and distribution of needed supply. Where a needed portion of current production cannot be maintained without a rise in price, because direct cost per unit has risen above price, or so close to price that there is an insufficient margin for contingencies and for the productive health of producers, then a price increase is in order. But where a higher price would have no effect on the volume of output, the enlarged revenue merely going into profits or wages, or both, justification is less obvious. It should be made clear, however, that the general principle here set forth would permit price increases where profits were so low that producers of essential goods could not make improvements required for greater efficiency, maintain the efficiency of the technical staff, provide against contingencies, and so forth. Similarly, price increases are justifiable if required in order to raise subnormal wages, because the profit margin is too thin to stand the wage increase.

We have spoken of prices in relation to "needed supplies" rather than maximum production. To all of us who have been accustomed to think in terms of maximum production of goods proportioned to freely-expressed consumer demand, the phrase "needed supplies" brings a shock. But in a war economy the production of many civilian goods must be curtailed, some drastically, some moderately. In large measure this can best be achieved by direct methods-curtailment and allocation programs. Price control is, however, a useful supplementary instrument. Prices should not be so high as to make evasion of the curtailment or allocation orders highly profitable. Secondly, where change-over from civilian to war production is possible, prices on the civilian goods must not be so high as to make their production more profitable than that of war goods. Again, it is obviously more difficult to allocate labor by direct methods than to allocate materials and machinery by such methods. Wherever allocation of labor is imperative in order to achieve production of several different commodities in certain proportions needed for the war effort, the relative prices on these commodities should not be such as to encourage greater production of one than is needed, at the expense of less production of the others. It must be emphasized, however, that price control alone is likely to prove inadequate in the long run as a means of achieving the desired allocation of manpower to most important

\footnotetext{
- An increase in selling price (or its equivalent in revenue) does not necessarily imply that this must be passed on in the form of commensurate increases in selling prices at later stages of production and distribution. Processors or distributors at later stages may be able to absorb the price increase. Moreover, the Office of Price Administration and other government agencies are empowered by the Act to use buying and selling programs or subsidies to achieve maximum necessary production. $\$_{2}(e)$.
} 
uses, and to prevent uneconomic shifting about of labor. A more vigorous policy of wage stabilization and even direct allocation controls may well become necessary as the shortage of certain types of labor grows more acute.

We have said that the major problem is to develop criteria by which to assess potential or requested price increases. In a defense program inaugurated when most industries are operating below capacity, the typical pattern of development in those industries whose supply of materials or labor is not curtailed is expansion of output accompanied by falling unit costs for a time. Profits increase, often strikingly. Energetic labor unions are able to obtain increases in wage rates. Other wage increases come automatically because they are required to prevent transfer of skilled labor when shortages develop early. Some price increases on materials occur. Finally, as output is pushed beyond the point of most efficient use of plant, in the sense of lowest cost use, unit cost begins to rise for familiar reasons. In extractive industries such as mining, rising unit costs may be encountered sooner owing to technical conditions such as the existence of different grades of ore, differences in depth of mining, differences in structure of ore deposits, and the like.

As long as price is above total cost per unit and unit cost is declining with expansion of output, profits are increasing and there is obviously no justification for a price increase. As long as price remains above the cost added to total cost by additional output and profits increase with growing output, there is generally no justification for a price increase. Only when the out-of-pocket costs per unit or the additional cost of extra units of output increase, either because of increases in the prices of materials or wage rates, or because unit costs rise with expanded output, does any question of a justifiable price increase ordinarily occur. From the standpoint of the objectives outlined above, the criterion that every increase in direct or out-of-pocket cost justifies an increase in price by a corresponding amount, is not a correct standard, however familiar and pleasing to managements. Rather the criterion should be that increases in direct cost should be absorbed as long as maximum needed production is still possible. Wherever the margin between price and direct cost per unit has been large this may mean that cost increases can be absorbed for some timeespecially if increases in wage rates or material costs are moderate and unit costs increase slowly.

These economic criteria for assessing the justification of price increases apply also, of course, to cases where prices have risen before control was applied. The amount of the appropriate reduction, if any, is indicated by application of the same criteria. It is obvious, however, that if price increases are permitted to endure for some time before control is imposed, increases in cost elements may have been induced, with the result that application of these criteria will give a higher price than they would have indicated earlier.

Most of the public attention in relation to war price administration has been focussed on prevention of price increases. It is worth emphasizing that price reductions may greatly facilitate promotion of the objectives of war administration, par- 
ticularly where an inflationary price increase has already occurred. Price reductions which prevented undue increase in profit rates, wage rates, or prices paid for materials would, indeed, be effective in limiting the expansion of credit and in choking the first stages of inflationary impulses that spiral into other industries. Reductions which lower the cost to the government of war goods tend to lower the government debt and the inflationary gap. ${ }^{6}$ Reductions which permit continuance of stable prices at later stages of production or distribution are obviously advantageous.

We have said that the basic economic criterion for price increases is maintenance of needed supply or expansion to the needed volume. It is now plain that in most cases this will come down to a criterion in terms of profits. In a strict economic sense the appropriate standard would be profits merely adequate to achieve the objective. Notions of fairness which mean something somewhat different from sheer adequacy in the sense used above are, however, common and widespread. Hence they should be woven into the standards for maximum prices and Congress has recognized this by providing that maximum prices are to be "generally fair and equitable" and that the "general increases or decreases in profits" of sellers are to be given consideration in fixing maximum prices.

There are two possible alternative concepts of fair profits. One runs in terms of a percentage of return on investment, the other in terms of dollar volume of profits. The former is familiar, in the notion of "fair return on fair value," as an instrument for accomplishing in monopolistic industries producing services of great public interest the results which were supposed to flow from competitive forces in other industries. The theory of "fair return on fair value" is, in our judgment, not applicable to the program of war price control with objectives which we have outlined above. The problem is not one of attracting capital to a relatively few regulated industries, protecting their investors from regulations that would reduce their earnings below what they would receive in unregulated industries of similar risk factors, and protecting consumers from monopolistic exploitation. Rather it is a problem of protecting all the various groups in the community from the cruel inequities of severe inflation and at the same time promoting the maximum production and flow of the needed supplies of war goods and essential civilian goods. Moreover, as a practical matter, war price control must be capable of rapid and flexible operation. Determination of fair value for a utility or transportation company has often taken many years. Any attempt to base maximum prices in war time on a fair valuation process would constitute a reductio ad absurdum that would greatly cheer the spirits of our enemies. Valuation is a dubious luxury that we can, perhaps, afford in peace-

\footnotetext{
${ }^{\circ}$ Price reductions are also desirable where the effect is to expand production and consumption of civilian articles that may be substituted for other goods whose civilian consumption is drastically reduced. Provided this means a net increase in civilian output and consumption with an elastic demand for the substitute articles, such price reductions would also have the beneficial effect of an increase in expenditure on them, leaving consumers less to spend on other things and hence reducing the inflationary pressure on those civilian goods whose production is not expansible or is curtailed. Expanded civilian production of price-reduced articles becomes increasingly less feasible, of course, as more and more resources must be converted to war use, except where the resources required for such civilian items are not convertible to war production.
} 
time. In wartime it would be criminal pettifogging. Hence it would not be consistent with the expressed purposes of the Act. The notion of fair rate of profit on investment could indeed be applied in short-cut fashion by taking book figures of investment and average rates of return earned in some past period. But this would come to much the same result as the use of dollar volume of profits in the same pre-war period and would have the disadvantage of much more computation. Application of a flat percentage return on investment in all industries would be inadvisable. In some cases the resulting maximum prices would be too low to accomplish the objectives, in other cases unnecessarily large price increases would have to be permitted.

A criterion of dollar volume of profits in a recent pre-war period is much superior to those just discussed. Its logic is based on the premise that the conditions permitting higher prices and larger profits are themselves due to the war rather than to the efforts and activities of firms or industries or to fortuitous peacetime developments. Use of this standard would tend toward approximation of the pre-war relative profit situation as between firms and industries, insofar as price control affects the matter. The dollar volume of profits of a firm in the pre-war period, must, of course, be adjusted for a return on any net increase or decrease in investment during the interim.

Given the guiding principle that, in general, individuals should not profit from the peculiar economic circumstances created by war, especially when millions of others are adversely affected by these same conditions, even to the point of sacrificing their lives, a reasonable formula would relate wartime profits to the best estimate of what profits would have been in the absence of war; and that best estimate might reasonably be based upon the earnings of enterprises in a near pre-war period, making allowance for changes in invested capital.

In many instances use of the period 1936 -x 939 would accord with what has been said above. In some instances, however, the amount of profits earned in that period might be insufficient to sustain the supplies needed now. In other instances the profits of a shorter period, such as the year 1940, or the twelve months preceding October I, 194I, might be more appropriate on the grounds that war influences had not yet made themselves felt in these cases.

It should be noted that profits must be interpreted to mean profits before income and excess profits taxes. Otherwise, the express intent of Congress as to the distribution of the war burden, in terms of the incidence of taxes, would be vitiated. In other words, if the price authorities followed the policy of relating war profits after taxes to peacetime profits, they would defeat the efforts of Congress to impose higher income taxes upon business concerns as a means of distributing the costs of war among various income groups.

Before departing from the question of "fair profit," it is perhaps worth emphasizing that the price control authorities should not be held responsible for guaranteeing profits to all concerns, through appropriate price adjustments. In the first place, such 
a policy would entail providing wartime profits to concerns that were unable to earn profits in peacetime markets. Second, the price agency would find itself in the ridiculous position of endeavoring to offset the numerous economic hardships of war created by factors beyond the pale of price control, such as curtailment of rnaterials for civilian commodities. This would amount to a widespread system of granting indirect subsidies via the price structure in a manner which would be not merely arbitrary and capricious but which would discourage rapid conversion of facilities to war use and distort thoroughly the balance and function of the price structure. Finally, such a policy of encouraging universal wartime profits might well result in ruinous misdirection of the price control program, away from its prime objectives.

Our discussion so far has concerned the level of prices for an industry or a firm. Price administration must also concern itself with the structure of the relative prices for different grades, constructions, lines, or products produced by a firm or an industry. Where determination of such price differentials is not important for the objectives of price control and where informal controls are effective, such determination can be left to management, the price control agency concerning itself only with the level of prices. Where the price differentials exercise an important influence on the relative volume of output of war goods and civilian goods, and of more essential and less essential goods, the price agency may need to participate in determination of such differentials even though no formal ceiling schedule is required.

Where a ceiling schedule is necessary, differentials-at least the more important ones-must be set in the schedule. In many cases typical or customary differentials, derived from recent price history, constitute the best criterion.' A supplementary criterion which seems satisfactory is that an individual price does not need to be increased provided it covers the out-of-pocket cost of the thing in question and provided the total profits of the firm, or of the bulk of the firms in the industry, are adequate and fair. These standards must sometimes be modified when the relative volume of output of different things is a matter of significance and when special considerations affect relative volume. In wartime, however, it is often desirable that firms temporarily abandon strict commercial principles for pricing of different lines or products. For example, quite apart from relative profit considerations, repair parts and strip models should be sold at relatively low prices.

When, as, and if an over-all freeze of all prices becomes necessary the problem of adjustments in relative prices may become more important.

\section{Techniques and Criteria Applied to Special Problems}

To illuminate briefly the application of the techniques and standards discussed above let us examine their practical application to two specific problems confronting the price authorities: (I) securing high-cost supply with minimum inflationary effect; (2) stabilizing prices of unstandardized commodities.

The first problem arises because different increments of the supply of a com- 
modity generally have different costs. Such cost differences are likely to be more marked in a war economy, because it is imperative to achieve "all out" production, both to maximize the output of war goods and to attain the largest production of civilian goods consistent therewith. "All out" production requires the use of existing operating facilities beyond their most efficient rates of output under ordinary calculations. It also requires the development of increments of output from mines and old plants or factories that have long been idle because of excessive costs. In the last war the price control authorities applied the theory of uniform, bulk-line maximum prices-i.e., prices adequate to secure the great bulk of the output. Use of this principle may not enable maximum possible production, and results in obtaining the higher cost increments only by great price increases, in other words by inflation. Maximum needed production without severe inflation can be accomplished by the use of differential prices-a base price for a part of the output and one or more higher prices for additional increments. A differential price scheme, effectively designed and carried out, can minimize the cost to government and to private con- sumers, minimize the amount of price-induced creation of credit, minimize the inflationary repercussions in other industries of wage-rate advances that merely reflect a large increase in price, and prevent the pyramiding in subsequent stages of a marked price increase on materials or semi-processed goods.

Determination of the base price and the higher differential prices must be partly a matter of expediency but some standards can be laid down. In general the ideal would be a set of prices which would minimize the total cost of the output to consumers, for this set of prices would best promote the other ends in view also. Often such precision is unattainable in practice, and cruder standards must be employed. If the ascertainable cost curve for the industry's total supply rises sharply after a certain output point, that is an obvious point at which to set the maximum base price. $^{7}$

Again, where a given uniform price has ruled for some time prior to introduction of differential pricing, it may be best to designate that price as the base price and build differential prices above it. In setting the height of differential prices it is important to strike a balance which will permit maximum needed production without bringing unnecessary increases in profits or wage rates which threaten both the maximizing of additional output and the volume of production forthcoming at the base price.

So far in the discussion of differential pricing we have been speaking of prices paid to producers for different increments of output. With regard to prices paid

\footnotetext{
${ }^{7}$ For example, suppose the maximum potential supply of a metal is one million tons, and a price of $25 \mathrm{c}$ per pound would be required to bring out this amount, at a total expenditure of $\$ 500$ million. A differential pricing system could reduce the total expenditure by establishing a base price, at which a large portion of the total would be produced, and a premium price or prices which would stimulate production of the remainder. Let us say that the $\$ 500$ million could be reduced to $\$ 380$ million by establishing a base price of $15 \mathrm{c}$ at which $60 \%$ of the total potential supply (i.e., 600,000 tons) would be forthcoming, together with a "premium price" of $25 \mathrm{c}$ at which the remaining $40 \%$ (or 400,000 tons) would come out. The net saving would be $\$ 120$ million.
} 
by consumers there are several alternatives. In the first place, producers may be permitted to sell the higher-cost increments of output, at prices above the ceiling base price, to whatever consumers are willing to pay the higher prices. This is the simplest arrangement but it has the obvious disadvantages of arbitrary discrimination between consumers and the promotion of unnecessary inflation at later stages of production. A second alternative is to classify consumers into groups to each of which the price is different. The groups could be distinguished according to degree of essentiality of use. The least essential uses could then be charged the highest prices, the next least essential the next highest prices, and so on. This scheme involves extraordinary difficulties in the case of pricing of a basic material such as any of the chief metals or textiles which go through many stages of fabrication. Thirdly, the Government may purchase all of the increments of output which command differential prices above the ceiling and resell them at the ceiling price, taking whatever loss is involved, or the Government may pay subsidies amounting to the difference between the "purchase" price and ceiling price, an arrangement that is administratively simpler and is being used in the premium price plan for copper, zinc, and lead. Where the highcost output goes to private consumers rather than government agencies, this is obviously the best arrangement. Especially is this so when the Government is allocating the total output. To the extent that government agencies buy the production directly, they may be charged the higher differential prices. Assuming that the Government uses the high-cost output it makes no difference, of course, whether the consuming government agency pays the high price or the purchasing government agency takes a loss in sale to the consuming agency. Finally, the Government might reserve for itself a needed portion of the lower-cost output and sell the remainder to the public at a selling price representing an average of the prices paid for all of the higher-cost increments. This would involve government purchase of the total output. This pricing scheme has the disadvantage of permitting more inflation in the general structure of prices than is desirable or necessary.

A differential pricing system operated by subsidy or purchase and resale at a loss is in effect in the cases of copper, zinc, lead, aluminum, nickel, and Chilean nitrates. Viewed narrowly, it appears that the Government "takes a loss" in these arrangements, yet it is obvious that, in terms of total supply, the nation has saved a considerable amount. ${ }^{8}$ To this direct saving must also be added the savings in terms of prevention of pyramided price increases at later stages of processing and indirect inflationary influences on other industries.

Closely related to the problem of securing high-cost domestic production by noninflationary means is the problem of handling high-cost imports. Here again it is desirable for the high-priced portion of total supply-represented by imports-to be handled separately from the lower-cost domestic supply, as an alternative to raising

\footnotetext{
${ }^{a}$ For example, in the illustration given in note 7, supra, the Government would have taken an apparent loss of $\$ 80$ million if it had paid $25 \mathrm{C}$ a pound for the 400,000 tons which it resold at $15 \mathrm{c}$. However, the purchasers would have saved \$200 million, and the net saving to the nation would be $\$ 120$ million.
} 
the domestic base price to the level necessary to encourage importation of much needed material. A government buying agency which will purchase all imports requiring a price above the domestic base price and "take a loss" if necessary in reselling such material will save large amounts for the nation as a whole and help prevent inflation.

Another problem suggested earlier-that of stabilizing the prices of unstandardized items, such as metal castings, machinery, and machine shop products-is an exceedingly difficult one which taxes the ingenuity of the price authorities for a workable solution. A uniform fixed price for all producers is obviously not feasible, since no two producers make identical items. Similarly, the freezing of prices existing in a specified base period for each producer does not solve the problem completely, for such a technique takes no account of "tailor-made" items manufactured for the first time subsequent to the base period. The method actually used in a considerable number of such cases by the Office of Price Administration has been to freeze the pricing method or formula of a company so that any item produced for the first time after the base period is priced as it would have been priced in the base period. In order for such a method to function effectively as a curb on inflation, it requires freezing the "cost ingredients" of a producer's pricing formula, as of the base period, so that any subsequent increases in the prices of labor or materials must be absorbed.

\section{Problems of a Broad Ceiling}

Finally, there is the problem of techniques and criteria to be employed in administering a broad ceiling over the prices of a wide range of items manufactured or distributed by a large number of concerns. This is the task which the Office of Price Administration may have to undertake in the near future.

As indicated earlier, selective price control becomes inadequate as a means of achieving the objectives of war price control when inflationary pressures become generalized. By the end of the first quarter of 1942 it was apparent that the American economy was threatened by a mounting inflationary tidal wave. The only effective measure against such a deluge is a broad price freeze.

Such a broad freeze creates a formidable set of problems for the price agency. Much attention must be devoted to unscrambling various price abnormalities which happened to exist during the base period and hence became frozen into the price structure. A more important problem concerns individual and group hardships resulting from the uneven movement of related prices prior to the base date. These problems resulting from a general freeze require considerable changes in the price agency's operating methods, as well as modifications of the more detailed criteria discussed earlier. Obviously, it is not administratively possible under a broad ceiling which covers thousands of commodities and millions of buyers and sellers to achieve the same intensive analysis of individual cases and the same detailed application of criteria that are feasible under narrower ceilings over fewer items. At the outset, at least, such a general price action must define whole classes of cases and develop 
techniques and criteria for handling such problem groups, rather than designing tailor-made solutions to fit individual cases.

Some of the problems of administering a broad ceiling over retail prices may be reviewed briefly. The core of the problems at the retail level is the so-called "squeeze" which may result from a time lag between the upward movements of wholesale and retail prices. The frozen price for an individual retailer or a group of retailers for a particular commodity may reflect a normal mark-up over the cost of present inventories purchased some weeks or months before the basic freeze date, at wholesale prices which subsequently moved up and became frozen at higher levels. Where this is the case and retailers are faced with the prospect of higher cost to replenish stocks, they find their margins squeezed between the frozen wholesale and retail levels. Since in some cases there is no time lag and hence no "squeeze" and because, where these elements are present, they vary widely for different commodities and different retail outlets, there is no feasible technique for avoiding the whole problem in the initial imposition of the general freeze. Hence, there soon arise numerous cases requiring some form of adjustment, and it is here that the price authorities must design techniques and criteria for classifying and disposing of many individual and group problems expeditiously.

In seeking a solution for such cases, the one all-important objective of the program must be kept in mind: namely, that the general retail level of no commodity price should be allowed to rise. In other words, a price "freeze" must be taken literally if it is to be successful. Granting of exceptions which allowed consumer prices to rise would quickly result in undermining the whole program. Abnormalities may be resolved by permitting an individual retailer to raise his frozen price up to the level of his competitors' prices on the same commodity, but this does not entail any general increase in the retail price of the commodity.

Where a large number of retailers of the same sort are "squeezed," the solution must lie in the direction of "rolling back the squeeze," or some part of it, to their suppliers. "Rolling back the squeeze" would involve reducing the wholesale price to a point which would give the retailers an adequate operating margin. This could be accomplished in some instances by a voluntary reduction by the supplier, but it might require removal of the commodity from the general freeze and establishment of somewhat lower maximum prices by a separate price schedule.

"Roll back" problems may exist at other stages of production and distribution as the result of a broad freeze. The criteria discussed above may be used in distributing between the several stages the necessary amount of "roll back." A broad freeze would also be attended by special problems not encountered in setting specific schedules of maximum prices so that development of special criteria to handle these would be necessary.

Should situations develop in which margins according with the general criteria outlined above were impossible of achievement at all stages by means of the "roll back" process, then it might be necessary to inaugurate government purchase and 
sale arrangements whereby cost relief could be give some concerns, thus making possible the maintenance of adequate margins at all stages. If such arrangements should become necessary they could be applied with greatest administrative efficiency at the manufacturing or material stages where the number of firms and products is less than in the distributive stages.

Closely related to "rolling back the squeeze" is the basic question of keeping particular kinds of concerns alive in the face of economic adversity. Surely no businessman or government official today nourishes the illusion that an all-out war can be conducted without severe economic hardships, which unfortunately do not fall upon each individual in accordance with his ability to bear them. It cannot be too much emphasized that the price agency can obviously not assume responsibility for all economic hardships resulting from war conditions. In the case of retailing, for example, the sharp curtailment of production of many civilian items is certain to shrink the physical volume handled by retailers in general and impose hardships particularly upon narrow-line retailers who formerly specialized in merchandise now curtailed, such as consumer durable goods. Here, as in the case of civilian goods manufacturers, the price agency should not be expected to stabilize profits.

The job is not one for government officials to handle alone. Much reliance must and can be placed upon the ingenuity of the American businessman to find ways of economizing on the various components of his goods or the attendant services, without seriously reducing the essential utility, so as to come out at least even. The price agency should aid the businessman in this endeavor; but it cannot rescue those who wish to rely entirely on government assistance. The problem of administering a broad price freeze is fraught with severe difficulties which can be overcome only by the highest degree of cooperation and understanding among businessmen, consumers, and Government. Government officials have the responsibility of making the spirit of regulations as clear as possible; individuals have the responsibility of conducting themselves in accordance with the defined intent of such regulations. Nothing could more effectively sabotage the whole war effort than a widespread effort of individuals to seek loopholes in the written words of regulations or to succumb to the temptation of cutting corners simply because the nation cannot spare sufficient manpower in the present crisis to police every individual action. Certainly the behavior of Americans generally in the war effort thus far affords hope for the success of our present battle against war inflation. 